\title{
THE POOLING OF FREIGHT CARS
}

\author{
By J. R. Cavanagh,
}

Superintendent Car Service, Cleveland, Cincinnati, Chicago and St. Louis Railway Company, Indianapolis, Ind.

The inability of many of the railroads of the country, or portions of numerous other railroad systems, to handle promptly the freight offered for transportation has increased the importance of devising some method of adding to the efficiency of the enormous freight car equipment now in use upon American railways. There is no topic in railway management more discussed than the car shortage or car surplus question.

This is a comparatively recent problem that has arisen as the result primarily of the enormous increase in traffic during the past seven years, and secondarily of the steady development of through shipments or long-distance traffic. The development of the country, the widely distributed population and industry, and the growing unification of the transportation business of the country as a whole are causing the former method of interchanging cars to become antiquated and practically unworkable.

Prior to 1872 connecting railway companies did not exchange freight cars regularly except in the case of cars that were assigned to freight lines and which were marked and known as "line cars." The payment for the use of cars that were interchanged was made by junction agents at the rate of two cents per loaded mile run. In 1872 this charge was reduced to one cent per mile run, loaded or empty, settlement being made by the accounting department of the company borrowing the car by a report made to the corresponding department of the company owning the car. In August, 1876 , the payment per mile run was reduced to three-quarters of a cent, and later a further reduction to three-fifths of a cent was made, the charge in each case being for the entire distance traveled by the car, whether loaded or empty.

This system of payment upon the basis of mileage proved fairly satisfactory during the prosperous years preceding 1893 . Then

(260) 
when the panic came which was followed by a period of five years of business depression, the railroads of the country were troubled with a surplus rather than with a shortage of equipment. Many roads were glad to have their equipment used by other companies. During the period from 1893 to 1899 there was comparatively little increase in the freight car equipment, and the consequence was that when business became active, just before I900, every railroad soon began to clamor for cars. The situation which began to develop in I899-1900 has grown steadily more acute year by year, until at the present time every railroad company is obliged to confess itself unable to supply the shippers promptly and adequately with a sufficient number of cars.

Various efforts have been made to deal with this steadily increasing difficulty and perplexity. As a result of an agitation in I9OI the railroads of the United States on the Ist of July, I902, changed the basis of settlement for the use of foreign cars from miles run to a per diem basis. The payment agreed upon was twenty cents per day, the owner of the car having the right to demand its return when the car had been absent from its lines twenty days. If the car was not returned within ten days thereafter, viz., thirty days from the time it left the line of the owning company, the per diem charge was advanced from twenty cents to one dollar. It was hoped that this change in the payment for the use of foreign cars would solve the question. It did, indeed, prove to be much superior to the mileage basis of payment, and experience has shown that time is a better standard than mileage in fixing the charges for the rental of cars.

A fundamental defect in the per diem penalty plan of charging for the use of foreign cars is becoming evident: it has had the effect of pooling cars moving in the direction of roads receiving large volumes of inbound business, and of taking equipment away from the lines of roads having a large outbound traffic. Thus, for instance, road A. might deliver I,O00 cars to road B. in a month, while during the same time road $B$. would have only 600 carloads of freight for delivery to $A$. If under these conditions $B$. had an unusual demand for cars, it would retain the 400 cars thus received in excess of those given it and use the same to carry on its business with other companies, viz., to supply its own equipment needs. The method of paying for the use of foreign cars does not insure a 
prompt return to road $A$. of the equipment sent out by it in excess of the equipment received in the transportation of traffic coming to it from connecting lines. Railroad companies that are large originators of traffic are easily denuded of equipment, and are without the power under the present rules to get their cars back within a reasonable time.

As the demand for cars has increased, as storage facilities have become inadequate with the growth of traffic, and as the average number of miles which a carload of freight is moved has grown greatly, the per diem of twenty cents has come to be entirely inadequate. This fact was so clearly recognized by railroads that on the Ist of January, Ig06, the per diem was raised to twenty-five cents per car, with a per diem penalty of seventy-five cents additional at the end of thirty days. This increase was soon shown to be insufficient, and the result was that in the autumn of 1906 a number of railroads agreed among themselves to charge each other, temporarily, a per diem of fifty cents, without the penalty feature. The roads which did not become parties to this agreement have continued to charge the old rates of twenty-five cents per day, increasing to one dollar per day to the end of thirty days.

Even the per diem charge of fifty cents has not met the situation. There is still a severe car shortage, and it will be impossible for the railroads to secure from the car builders a sufficient number of cars during the present calendar year to relieve the situation. At the close of January, 1907, a number of railroads agreed to enter a freight car pool, provided a satisfactory plan for regulating such a pool could be worked out. Thus far no practical plan has yet been presented. Everybody seems to recognize that the per diem systen of payment ought to be changed, but the problem of working out a car pooling arrangement that is satisfactory to all parties in interest has thus far proven impossible of solution.

One thing, however, is certain: the rules that have been recommended providing for the return of cars as per marks or ownership are impracticable, for the reasons that every restriction placed upon the fnovement of a car reduces its availability, increases the mileage which it travels without a load, and adds to the time and expense required for switching. Some plan must be found for controlling the movement of freight cars before traffic officials can hope to discover a practical solution of the problem. 
In order to deal adequately with the distribution and movement of cars a system must be established that will be in accordance with the following principles:

I. Equity must be secured alike to owner and user of the car, viz., to both delivering and receiving lines.

2. The payment must reward the efficient use of equipment and adequately penalize its inefficient use.

3. The reward should be in proportion to the degree of merit, and the penalty should correspond with the degree of the offense.

4. The system of control should minimize operating expenses as far as possible, and should provide definitely for settlements day by day or week by week between the delivering and receiving lines.

5. No unadjusted discrepancies between car owner and user should be permitted.

6. The system should insure to each road the full use of its own equipment, or of cars providing an equivalent equipment.

7. The system should provide for maximum loads, and should minimize as far as possible the empty-haul mileage.

In the opinion of the writer these principles of car control and distribution can be carried out in practice only by a system of pooling freight cars in accordance with an equitable arrangement that will prevent the appropriation by any one or more lines of the larger and better cars, and that will provide for a daily settlement between delivering and receiving lines. This system would minimize the expenses of operation and maximize the efficiency of the equipment. As the result of a careful study of the subject and of business experience, the author recommends the following plan for the organization and management of a freight car pool. He believes that it solves every element of the problem, and that its adoption by the railroads generally in the United States would enormously increase the effciency of their freight equipment.

\section{Suggrsted Plan.}

I. An inventory to be taken of every car on each line, home and foreign, at $\mathrm{r} 2.0 \mathrm{I}$ a. m., date of beginning of plan.

2. A statement of equipment owned at r2.or a. m., date of operation.

3. The difference between ownership and actual cars on hand to constitute a debit or credit, as the case may be.

4. Each day at 12.01 a. m., a report to be rendered, in triplicate, by each agent, of cars delivered to connecting lines, to the agent of such line, for the 
twenty-four hours preceding; such reports to be checked and verified by both agents (or preferably by a joint clerk) one copy to be kept by the receiving agent, two copies to be returned to the delivering agent, one for his file and one to be forwarded, with notations thereon, to the district manager of the pool. The receiving agent to be required to take an impression copy and send the original to his car accountant.

5. In case of omissions, errors or discrepancy in statements, such discrepancies to be adjusted within twenty-four hours, the delivering line, in the meantime, assuming the expense of car hire until it proves delivery; if not adjusted in ninety-six hours then the inspector of the pool to investigate, and his report must be accepted by both lines, subject to appeal to the district manager.

In all cases of dispute, when finally decided, all errors and omissions to be adjusted on current interchange report, which report shall show dates, initials and car numbers "as reported" and "as should have been reported," also difference "Dr." or "Cr."

6. In cases where such discrepancies become chronic, the pool to place a joint man to locate the responsibility; the expense of such joint man to be paid by the road at fault.

7. The balance Dr. or Cr. to be carried forward each day; the cars delivered the current day added, the cars received deducted, and balance Dr. or Cr. shown and certified to. Not later than the 5th of each month a summary of the past month to be rendered by the agent of the delivering line to the agent of the receiving line, showing, by date, the daily balances, which must be certified to at once.

8. The Dr. balance to be paid for at such flat rates as may be agreed upon, or may be based on some sort of a graduated plan about as follows:

First fifteen days at..............25 cents per car per day.

The sixteenth day at $\ldots \ldots \ldots \ldots \ldots \ldots$

The seventeenth day at $\ldots \ldots \ldots \ldots \ldots 35$

The eighteenth day at $\ldots \ldots \ldots \ldots$.

The nineteenth day at $\ldots \ldots \ldots \ldots \ldots .45$

The twentieth day at $\ldots \ldots \ldots \ldots \ldots$. 50

The twenty-first day at ........... 55

The twenty-second day at ........60

The twenty-third day at $\ldots \ldots \ldots \ldots 65$

The twenty-fourth day at .........70

The twenty-fifth day at $\ldots \ldots \ldots \ldots \ldots 75$

The twenty-sixth day at ..........80

The twenty-seventh day at $\ldots \ldots \ldots .85$

The twenty-eighth day at ..........90

The twenty-ninth day at ..........95

\begin{tabular}{|c|c|c|c|}
\hline at & " & $"$ & a \\
\hline ax & or & " & " \\
\hline at & " & “ & " \\
\hline "a & sc & " & " \\
\hline "6 & a & or & $"$ \\
\hline or & a & " & " \\
\hline Ir & ، & " & " \\
\hline 'r & " & " & " \\
\hline ac & " & "s & “ \\
\hline a & "a & " & " \\
\hline If & s6 & a & " \\
\hline a & "s & " & "c \\
\hline as & 16 & w & " \\
\hline
\end{tabular}

The thirtieth day at \$I per car per day; and thereafter at $\$ \mathrm{I}$ per car per day. 
The holding of any individual car in excess of 60 days to be charged for at agreed rate per car per day, in addition to the exchange balance rates, as may be agreed on. Another plan that suggests itself is, in addition to a fiat rate for Dr. balance each day to have an arbitrary percentage of all revenues received from freight, switching, car service, etc., deducted and Cr. to pool-to be divided pro rata on equitable basis, or used to maintain full quota of cars in pool.

9. All cars to be repaired on the line where cars are in bad order, under rules to be agreed upon by the M. C. B. of lines in the pool.

Io. Cars accepted in bad order to be transferred at expense of delivering line.

II. In cases of cars destroyed, such destruction of car to be reported by wire or United States mail; from date of such notice the road destroying the car to be entitled to a claim of not to exceed 60 days for re-building the car, or thirty days to pay for the same; if payment is made then the commissioner or manager shall credit such road and debit the car owner.

12. In cases of new cars built, such cars, when traveling under freight charges, shall not be counted in exchange account and shall be shown on interchange report as "new cars" and credit shown thereon; when surh cars are delivered to connecting road for service, then such road shall be debited with such cars, and owners credited. (Cars returned under M. C. B. route cards to be credited same as good-order cars.)

13. When a road cannot receive traffic on account of congestion, embargo, or other causes, it must protect itself by stopping receipt or loading for such line until interchange is resumed, or it may be arranged between such lines to hold such traffic and bill on line requesting cars held. (Make it a matter of local arrangement and in no way interfere with exchange account.)

14. In the case of cars in switching service, the roads in interest to arrange to bill each other for such cars for the actual time such cars are in the service of the carrier line, plus one day for switching and one day for the return of car. 